\title{
Marinobacter pelagius sp. nov., a moderately halophilic bacterium
}

\section{Correspondence \\ Min Wu \\ wumin@zju.edu.cn}

\author{
Xue-Wei Xu, ${ }^{1,2,3}$ Yue-Hong $\mathrm{Wu}^{3}{ }^{3}$ Chun-Sheng Wang, ${ }^{1,2}$ Jun-Yi Yang, ${ }^{1,2}$ \\ Aharon Oren ${ }^{4}$ and $\mathrm{Min} \mathrm{Wu}^{3}$
}

\author{
${ }^{1}$ Laboratory of Marine Ecosystem and Biogeochemistry, State Oceanic Administration, \\ Hangzhou 310012, People's Republic of China \\ ${ }^{2}$ Second Institute of Oceanography, State Oceanic Administration, Hangzhou 310012 , \\ People's Republic of China \\ ${ }^{3}$ College of Life Sciences, Zhejiang University, Hangzhou 310058, People's Republic of China \\ ${ }^{4}$ Institute of Life Sciences, and the Moshe Shilo Minerva Center for Marine Biogeochemistry, \\ The Hebrew University of Jerusalem, Jerusalem 91904, Israel
}

The genus Marinobacter was first proposed by Gauthier et al. (1992) with the description of Marinobacter hydrocarbonoclasticus. This organism, isolated from Mediterranean seawater taken near a petroleum refinery, was aerobic, extremely halotolerant and hydrocarbondegrading. A second species of the genus, Marinobacter aquaeolei, was proposed by Huu et al. (1999) to accommodate a moderately halophilic bacterium that was isolated from an oil-producing well at an offshore platform in southern Vietnam. M. aquaeolei, however, was later suggested to be a heterotypic synonym of $M$. hydrocarbonoclasticus (Márquez \& Ventosa, 2005). At the time of writing, the genus Marinobacter comprises a further 14 recognized species, namely Marinobacter litoralis (Yoon et al., 2003), M. lutaoensis (Shieh et al., 2003), M. lipolyticus (Martín et al., 2003), M. excellens (Gorshkova et al., 2003), M. flavimaris and M. daepoensis (Yoon et al., 2004), M.

The GenBank/EMBL/DDBJ accession number for the 16S rRNA gene sequence of strain $\mathrm{HS}^{2} 25^{\top}$ is DQ458821.

A scanning electron micrograph of cells of strain $\mathrm{HS}^{2} 25^{\top}$, phylogenetic trees based on $16 \mathrm{~S}$ rRNA gene sequences according to the maximumparsimony and maximum-likelihood methods and a table detailing the fatty acid compositions of Marinobacter strains are available as supplementary material with the online version of this paper. bryozoorum and M. sediminum (Romanenko et al., 2005), M. maritimus (Shivaji et al., 2005), M. algicola (Green et al., 2006), M. vinifirmus (Liebgott et al., 2006), M. koreensis (Kim et al., 2006), M. gudaonensis (Gu et al., 2007) and M. salsuginis (Antunes et al., 2007). Here, we describe a moderately halophilic bacterium that represents a novel species of the genus Marinobacter.

Strain HS225 ${ }^{\mathrm{T}}$ was isolated from coastal seawater samples collected from the Zhoushan Archipelago, Zhejiang Province, China. The marine environment of the Zhoushan Archipelago was described previously (Xu et al., 2007a). Halophilic medium (HM) used for isolation and maintenance of the strains was that described by Ventosa et al. (1982). The medium contained (per litre distilled water): $40.0 \mathrm{~g} \mathrm{NaCl}, 2.0 \mathrm{~g} \mathrm{KCl}, 1.0 \mathrm{~g} \mathrm{MgSO}_{4}, 0.36 \mathrm{~g}$ $\mathrm{CaCl}_{2} .2 \mathrm{H}_{2} \mathrm{O}, 0.23 \mathrm{~g} \mathrm{NaBr}, 0.06 \mathrm{~g} \mathrm{NaHCO}_{3}$, trace $\mathrm{FeCl}_{3}$, $10.0 \mathrm{~g}$ yeast extract (Difco), $5.0 \mathrm{~g}$ peptone (Difco) and $1.0 \mathrm{~g}$ glucose $(\mathrm{pH} 7.2)$. Water samples were filtered through 0.45 - and $0.22-\mu \mathrm{m}$ filters in sequence, and the $0.22-\mu \mathrm{m}$ membranes were then suspended in HM broth. After vigorous shaking for $15 \mathrm{~min}$, liquids were plated by using a tenfold dilution series method. Plates were incubated aerobically at $25{ }^{\circ} \mathrm{C}$. After 3-7 days inoculation, representative colonies were picked and maintained at 
$30{ }^{\circ} \mathrm{C}$. Strains were purified by repeated restreaking; purity was confirmed based on uniformity of colony morphology. Cell morphology and motility were examined by optical microscopy (Olympus BX40) and scanning electron microscopy (Cambridge S260) (see Supplementary Fig. S1 available in IJSEM Online).

The optimal conditions for growth were determined in $\mathrm{HM}$ with different $\mathrm{NaCl}$ concentrations $(0,0.5,1,3,5,7.5$, $10,15,20,25$ and $30 \%, \mathrm{w} / \mathrm{v})$. The $\mathrm{pH}$ range for growth was determined by adding MES ( $\mathrm{pH}$ 5.0-6.0), PIPES ( $\mathrm{pH}$ 6.57.0), Tricine ( $\mathrm{pH} 7.5-8.5)$ and CHES ( $\mathrm{pH} 9.0-10.0)$ to HM at a concentration of $25 \mathrm{mM}$. The temperature range for growth was determined by incubating over the range $4-48{ }^{\circ} \mathrm{C}$.

Single carbon source assimilation tests were performed by using a minimal medium (Shivaji et al., 2005). This medium contained (per litre distilled water): $40.0 \mathrm{~g} \mathrm{NaCl}$, $6.15 \mathrm{~g} \mathrm{MgCl}_{2}, 0.75 \mathrm{~g} \mathrm{KCl}, 1.45 \mathrm{~g} \mathrm{CaCl}_{2}, 1.0 \mathrm{~g} \mathrm{NH}_{4} \mathrm{Cl}$, $0.075 \mathrm{~g} \mathrm{~K}_{2} \mathrm{HPO}_{4}, 0.028 \mathrm{~g} \mathrm{FeSO}_{4}$ and $25 \mathrm{mM}$ PIPES/NaOH ( $\mathrm{pH}$ 7.2). The corresponding filter-sterilized sugar $(0.2 \%)$, alcohol $(0.2 \%)$, organic acid $(0.1 \%)$ or amino acid $(0.1 \%)$ was added to liquid medium. Acid production was investigated by using modified MOF medium supplemented with $1 \%$ sugars or alcohols (Leifson, 1963). The medium contained (per litre distilled water): $40.0 \mathrm{~g} \mathrm{NaCl}$, $2.5 \mathrm{~g} \mathrm{MgCl}_{2} .2 \mathrm{H}_{2} \mathrm{O}, 1.0 \mathrm{~g} \mathrm{MgSO}_{4} \cdot 7 \mathrm{H}_{2} \mathrm{O}, 0.5 \mathrm{~g} \mathrm{KCl}, 0.25 \mathrm{~g}$ $\mathrm{CaCl}_{2}$, trace $\mathrm{FeSO}_{4}, 0.5 \mathrm{~g}\left(\mathrm{NH}_{4}\right)_{2} \mathrm{SO}_{4}, 1.0 \mathrm{~g}$ casitone (Difco), $0.1 \mathrm{~g}$ yeast extract (Difco), $0.5 \mathrm{~g}$ Tris and $0.01 \mathrm{~g}$ phenol red ( $\mathrm{pH}$ 7.5). The substrates used for single carbon source assimilation and acid production tests are listed in the species description below.

Phenotypic characteristics, including oxidase and catalase reactions, $\mathrm{H}_{2} \mathrm{~S}$ production, hydrolysis of aesculin, gelatin, casein, DNA, starch, Tweens 20 and 80 , tyrosine and urea, indole production, phenylalanine deamination and antimicrobial susceptibility, were tested in HM according to the methods given in Mata et al. (2002) as described by Xu et al. (2007b). Sensitivity to antimicrobial agents was determined in HM containing each antimicrobial agent at $50 \mathrm{mg} \mathrm{l}^{-1}$ for at least 3 days. Antimicrobial agents used were ampicillin, bacitracin, carbenicillin, cefotaxime, chloramphenicol, erythromycin, kanamycin, nalidixic acid, neomycin, nitrofurantoin, novobiocin, nystatin, penicillin, polymyxin B, rifampicin, streptomycin and tetracycline. $M$. koreensis DSM $17924^{\mathrm{T}}$ and M. gudaonensis CGMCC $1.6294^{\mathrm{T}}$ were used as controls in these tests. Detailed results are given in the species description.

The 16S rRNA gene of strain HS225 $5^{\mathrm{T}}$ was amplified as described by Xu et al. (2007b). The sequence was compared with closely related sequences of reference organisms from the FASTA network service. Sequence data were aligned with CLUSTAL W 1.8 (Thompson et al., 1994). Phylogenetic trees were constructed by using the neighbour-joining and maximum-parsimony methods with the MEGA 3 program package (Kumar et al., 2004) and the maximum-likelihood method with the PHYLIP 3.6 program. Fatty acid methyl esters were obtained from cells grown in $\mathrm{HM}$ for $36 \mathrm{~h}$ at $30{ }^{\circ} \mathrm{C}$ and analysed by using GC/MS (Kuykendall et al., 1988). The DNA G + C content was determined by thermal denaturation $\left(T_{\mathrm{m}}\right)$ (Marmur \& Doty, 1962) with Escherichia coli K-12 DNA as a calibration standard. DNA-DNA hybridizations were performed by the thermal denaturation and renaturation method of De Ley et al. (1970) as modified by Huß et al. (1983), by using a Beckman DU 800 spectrophotometer.

$16 \mathrm{~S}$ rRNA gene sequence analysis indicated that strain HS225 ${ }^{\mathrm{T}}$ clustered within the genus Marinobacter (Fig. 1; see also Supplementary Figs S2 and S3). Phylogenetic analysis based on 16S rRNA gene sequence comparisons showed that strain $\mathrm{HS}_{22} 25^{\mathrm{T}}$ formed a coherent cluster with $M$. koreensis $\mathrm{DD}-\mathrm{M} 3^{\mathrm{T}}$ with high bootstrap resampling values ( $98 \%$ by the neighbour-joining method and $94 \%$ by the maximum-parsimony method). Strain $\mathrm{HS}_{22} 5^{\mathrm{T}}$ exhibited highest 16S rRNA gene sequence similarity to the type strains of M. koreensis and M. gudaonensis (98.1 and $97.7 \%$, respectively). 16S rRNA gene sequence similarity between strain $\mathrm{HS}_{22} 5^{\mathrm{T}}$ and the type strains of other recognized Marinobacter species, however, was below $97.0 \%$. Several phenotypic properties, such as growth and biochemical characteristics, were similar between strain $\mathrm{HS}_{2} 25^{\mathrm{T}}$ and recognized Marinobacter species, but many differences, especially hydrolysis of certain substrates, allowed them to be distinguished from each other (Table 1).

The major fatty acids of strain HS225 ${ }^{\mathrm{T}}$ were $\mathrm{C}_{16: 0} \omega 9 \mathrm{c}$ and $\mathrm{C}_{16: 0}$. These fatty acids were also predominant components of M. gudaonensis CGMCC $1.6294^{\mathrm{T}}$ and $M$.

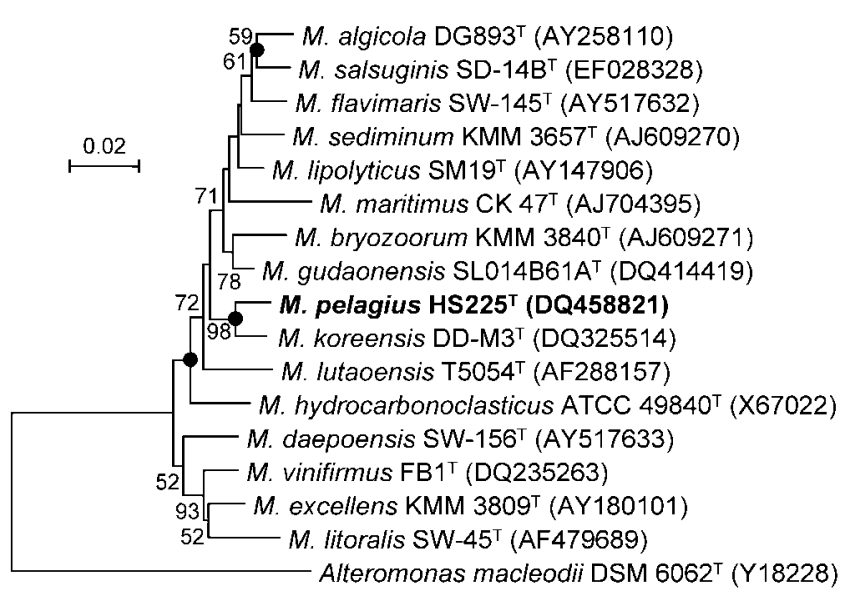

Fig. 1. Neighbour-joining tree based on 16S rRNA gene sequences, showing the phylogenetic relationships of strain $\mathrm{HS}_{22}{ }^{\top}$ and members of the genus Marinobacter. Bootstrap values are percentages based on 1000 replicates; only values $>50 \%$ are shown. Dots indicate branches of the tree that were also formed with the maximum-parsimony and maximum-likelihood methods (see Supplementary Figs S2 and S3). Bar, 0.02 substitutions per nucleotide position. 
Table 1. Differential phenotypic characteristics between strain $\mathrm{HS}_{2} 25^{\top}$ and related Marinobacter species

Taxa: 1, strain HS225 ${ }^{\mathrm{T}}$; 2, M. koreensis DSM 17924 ${ }^{\mathrm{T}}$; 3, M. gudaonensis CGMCC $1.6294^{\mathrm{T}}$ (data in columns 1-3 from this study unless indicated); 4 , M. algicola; 5, M. bryozoorum; 6, M. hydrocarbonoclasticus; 7, M. lipolyticus; 8, M. maritimus; 9, M. sediminum. Data for reference species were derived from Gauthier et al. (1992), Martín et al. (2003), Romanenko et al. (2005), Shivaji et al. (2005), Green et al. (2006), Kim et al. (2006) and Gu et al. (2007). +, Positive; -, negative; ND, no data available. DNA G+C contents were determined by the $T_{\mathrm{m}}$ method unless indicated.

\begin{tabular}{|c|c|c|c|c|c|c|c|c|c|}
\hline Characteristic & 1 & 2 & 3 & 4 & 5 & 6 & 7 & 8 & 9 \\
\hline Growth temperature range $\left({ }^{\circ} \mathrm{C}\right)$ & $4-48$ & $10-45$ & $10-45$ & $5-40$ & $7-42$ & $10-45$ & $10-41$ & $4-37$ & $4-42$ \\
\hline Urease & - & - & - & + & - & - & - & + & - \\
\hline Amylase & - & - & + & + & - & - & - & - & - \\
\hline Hydrolysis of Tween 80 & + & + & + & + & - & ND & + & + & + \\
\hline L-Arabinose & - & - & - & - & + & - & - & $\mathrm{ND}$ & + \\
\hline Cellobiose & - & - & - & - & + & - & - & - & + \\
\hline D-Fructose & - & - & + & + & - & - & + & + & ND \\
\hline Glucose & - & - & + & + & - & - & + & ND & + \\
\hline Maltose & - & - & + & + & + & ND & + & - & + \\
\hline Mannitol & - & - & - & + & + & - & + & + & + \\
\hline Citrate & - & - & + & + & - & + & - & + & - \\
\hline Gluconate & - & - & - & + & + & - & + & - & + \\
\hline Glutamate & + & + & + & + & - & + & - & - & - \\
\hline Succinate & + & - & + & + & - & + & - & - & $\mathrm{ND}$ \\
\hline DNA G $+\mathrm{C}$ content $(\mathrm{mol} \%)$ & 59.0 & $54.1(\mathrm{HPLC})^{a_{\star}}$ & $57.9^{b}$ & 55 & 59.6 & 52.7 & 57.0 & 58.0 & 56.5 \\
\hline
\end{tabular}

${ }^{*}$ Data from: $a$, Kim et al. (2006); b, Gu et al. (2007).

koreensis DSM $17924^{\mathrm{T}}$ (see Supplementary Table S1). However, $\mathrm{C}_{17: 0}$ was detected in strain $\mathrm{HS}_{22} 5^{\mathrm{T}}$ but not in M. koreensis DSM $17924^{\mathrm{T}}$. The DNA G $+\mathrm{C}$ content of strain $\mathrm{HS}_{22} 5^{\mathrm{T}}$ ( 59.0 mol\%, by $T_{\mathrm{m}}$ ) was notably higher than that of M. koreensis DD-M3 ${ }^{\mathrm{T}}$ (54.1 mol\%, by HPLC) (Kim et al., 2006). DNA-DNA hybridization experiments were carried out at $76{ }^{\circ} \mathrm{C}$. Levels of DNA-DNA relatedness between strain HS225 ${ }^{\mathrm{T}}$ and M. koreensis DSM $17924^{\mathrm{T}}$ and M. gudaonensis CGMCC $1.6294^{\mathrm{T}}$ were 46 and $44 \%$, respectively. Therefore, based on 16S rRNA gene sequence analysis, as well as DNA-DNA hybridization data and differential phenotypic properties, we suggest that strain HS225 ${ }^{\mathrm{T}}$ represents a novel species of the genus Marinobacter, for which the name Marinobacter pelagius sp. nov. is proposed.

\section{Description of Marinobacter pelagius sp. nov.}

Marinobacter pelagius (pe.la'gi.us. L. masc. adj. pelagius of the sea, marine).

Cells are Gram-negative and motile. Young cultures show rod-like cells $(2.0-4.0 \times 0.4-0.8 \mu \mathrm{m})$, occurring singly or in pairs. Colonies are $1-2 \mathrm{~mm}$ in diameter, smooth, circular, elevated and cream coloured after $48 \mathrm{~h}$ at $30{ }^{\circ} \mathrm{C}$.
Moderately halophilic. No growth occurs in the absence of salt. Growth occurs at $\mathrm{NaCl}$ concentrations of $0.5-15 \%$ $(\mathrm{w} / \mathrm{v})$, with optimum growth at $5.0 \% \mathrm{NaCl}$. The $\mathrm{pH}$ and temperature ranges for growth are $\mathrm{pH} 6.0-9.0$ and $4-48{ }^{\circ} \mathrm{C}$ (optimum growth at $\mathrm{pH} 7.0-8.0$ and $25-30{ }^{\circ} \mathrm{C}$ ). Oxidaseand catalase-positive. Nitrate is reduced. Tweens 20 and 80 are hydrolysed. Aesculin, casein, DNA, gelatin, starch, tyrosine and urea are not hydrolysed. Tests for indole production and phenylalanine deamination are negative. $\mathrm{H}_{2} \mathrm{~S}$ is produced from thiosulfate. Chemo-organotrophic. The following substrates are utilized for growth: acetate, Lalanine, fumarate, L-glutamate, L-isoleucine, lactate, malate, propionate, pyruvate, succinate and L-valine. The following compounds are not utilized as sole carbon sources: L-arabinose, L-arginine, L-aspartate, cellobiose, citrate, L-cysteine, ethanol, formate, D-fructose, D-galactose, gluconate, glucose, glycerol, glycine, L-histidine, myoinositol, lactose, malonate, maltose, mannitol, D-mannose, L-methionine, L-ornithine, raffinose, ribose, L-serine, Lsorbitol, sorbose, starch, sucrose and xylose. Acid is not produced from the following carbohydrates: L-arabinose, D-fructose, D-galactose, glucose, myo-inositol, lactose, maltose, mannitol, D-mannose, L-sorbitol, sorbose, sucrose or trehalose. Susceptible to ampicillin, carbenicillin, 
cefotaxime, chloramphenicol, erythromycin, nalidixic acid, nitrofurantoin, penicillin, polymyxin B, novobiocin and tetracycline, but not to bacitracin, kanamycin, neomycin, nystatin, rifampicin or streptomycin. Principal fatty acids are $\mathrm{C}_{16: 0} \omega 9 c(23.5 \%), \mathrm{C}_{16: 0}(19.5 \%), \mathrm{C}_{12: 0} 3-\mathrm{OH}(8.3 \%)$, $\mathrm{C}_{18: 1} \omega 9 c(7.4 \%)$ and $\mathrm{C}_{14: 0}(4.7 \%)$. The DNA $\mathrm{G}+\mathrm{C}$ content of the type strain is $59.0 \mathrm{~mol} \%\left(T_{\mathrm{m}}\right)$.

The type strain, HS225 $5^{\mathrm{T}}$ (=CGMCC $1.6775^{\mathrm{T}}=\mathrm{JCM}$ $14804^{\mathrm{T}}$ ), was isolated from seawater samples of the Zhoushan Archipelago, Zhejiang Province, China.

\section{Acknowledgements}

We thank Jean Euzéby for his help with the specific etymology and nomenclature. This work was supported by grants from the Major State Basic Research Development Program of China (973 Program) (grant no. 2004CB719604-3), the Key Project of Zhejiang Science and Technology (grant no. 2006C13053) and the Open Fund of Laboratory of Marine Ecosystem and Biogeochemistry, SOA (grant no. LMEB200703).

\section{References}

Antunes, A., França, L., Rainey, F. A., Huber, R., Nobre, M. F., Edwards, K. J. \& da Costa, M. S. (2007). Marinobacter salsuginis sp. nov., isolated from the brine-seawater interface of the Shaban Deep, Red Sea. Int J Syst Evol Microbiol 57, 1035-1040.

De Ley, J., Cattoir, H. \& Reynaerts, A. (1970). The quantitative measurement of DNA hybridization from renaturation rates. Eur $J$ Biochem 12, 133-142.

Gauthier, M. J., Lafay, B., Christen, R., Fernandez, L., Acquaviva, M., Bonin, P. \& Bertrand, J. C. (1992). Marinobacter hydrocarbonoclasticus gen. nov., sp. nov., a new, extremely halotolerant, hydrocarbondegrading marine bacterium. Int J Syst Bacteriol 42, 568-576.

Gorshkova, N. M., Ivanova, E. P., Sergeev, A. F., Zhukova, N. V., Alexeeva, Y., Wright, J. P., Nicolau, D. V., Mikhailov, V. V. \& Christen, R. (2003). Marinobacter excellens sp. nov., isolated from sediments of the Sea of Japan. Int J Syst Evol Microbiol 53, 2073-2078.

Green, D. H., Bowman, J. P., Smith, E. A., Gutierrez, T. \& Bolch, C. J. S. (2006). Marinobacter algicola sp. nov., isolated from laboratory cultures of paralytic shellfish toxin-producing dinoflagellates. Int $J$ Syst Evol Microbiol 56, 523-527.

Gu, J., Cai, H., Yu, S.-L., Qu, R., Yin, B., Guo, Y.-F., Zhao, J.-Y. \& Wu, X.-L. (2007). Marinobacter gudaonensis sp. nov., isolated from an oilpolluted saline soil in a Chinese oilfield. Int J Syst Evol Microbiol 57, 250-254.

Huß, V. A. R., Festl, H. \& Schleifer, K. H. (1983). Studies on the spectrophotometric determination of DNA hybridization from renaturation rates. Syst Appl Microbiol 4, 184-192.

Huu, N. B., Denner, E. B. M., Ha, D. T. C., Wanner, G. \& Stan-Lotter, H. (1999). Marinobacter aquaeolei sp. nov., a halophilic bacterium isolated from a Vietnamese oil-producing well. Int J Syst Bacteriol 49, 367-375.

Kim, B. Y., Weon, H. Y., Yoo, S. H., Kim, J. S., Kwon, S. W., Stackebrandt, E. \& Go, S. J. (2006). Marinobacter koreensis sp. nov., isolated from sea sand in Korea. Int J Syst Evol Microbiol 56, 2653-2656.
Kumar, S., Tamura, K. \& Nei, M. (2004). MEGA3: integrated software for molecular evolutionary genetics analysis and sequence alignment. Brief Bioinform 5, 150-163.

Kuykendall, L. D., Roy, M. A., O'Neill, J. J. \& Devine, T. E. (1988). Fatty acids, antibiotic resistance, and deoxyribonucleic acid homology groups of Bradyrhizobium japonicum. Int J Syst Bacteriol 38, 358-361.

Leifson, E. (1963). Determination of carbohydrate metabolism of marine bacteria. J Bacteriol 85, 1183-1184.

Liebgott, P. P., Casalot, L., Paillard, S., Lorquin, J. \& Labat, M. (2006). Marinobacter vinifirmus sp. nov., a moderately halophilic bacterium isolated from a wine-barrel-decalcification wastewater. Int J Syst Evol Microbiol 56, 2511-2516.

Marmur, J. \& Doty, P. (1962). Determination of the base composition of deoxyribonucleic acid from its thermal denaturation temperature. J Mol Biol 5, 109-118.

Márquez, M. C. \& Ventosa, A. (2005). Marinobacter hydrocarbonoclasticus Gauthier et al. 1992 and Marinobacter aquaeolei Nguyen et al. 1999 are heterotypic synonyms. Int J Syst Evol Microbiol 55, 1349-1351.

Martín, S., Márquez, M. C., Sánchez-Porro, C., Mellado, E., Arahal, D. R. \& Ventosa, A. (2003). Marinobacter lipolyticus sp. nov., a novel moderate halophile with lipolytic activity. Int J Syst Evol Microbiol 53, 1383-1387.

Mata, J. A., Martinez-Canovas, J., Quesada, E. \& Bejar, V. (2002). A detailed phenotypic characterisation of the type strains of Halomonas species. Syst Appl Microbiol 25, 360-375.

Romanenko, L. A., Schumann, P., Rohde, M., Zhukova, N. V., Mikhailov, V. V. \& Stackebrandt, E. (2005). Marinobacter bryozoorum sp. nov. and Marinobacter sediminum sp. nov., novel bacteria from the marine environment. Int J Syst Evol Microbiol 55, 143-148.

Shieh, W. Y., Jean, W. D., Lin, Y. T. \& Tseng, M. (2003). Marinobacter lutaoensis sp. nov., a thermotolerant marine bacterium isolated from a coastal hot spring in Lutao, Taiwan. Can J Microbiol 49, 244-252.

Shivaji, S., Gupta, P., Chaturvedi, P., Suresh, K. \& Delille, D. (2005). Marinobacter maritimus sp. nov., a psychrotolerant strain isolated from sea water off the subantarctic Kerguelen islands. Int J Syst Evol Microbiol 55, 1453-1456.

Thompson, J. D., Higgins, D. G. \& Gibson, T. J. (1994). ClustaL W: improving the sensitivity of progressive multiple sequence alignment through sequence weighting, position-specific gap penalties and weight matrix choice. Nucleic Acids Res 22, 4673-4680.

Ventosa, A., Quesada, E., Rodriguez-Valera, F., Ruiz-Berraquero, F. \& Ramos-Cormenzana, A. (1982). Numerical taxonomy of moderately halophilic Gram-negative rods. J Gen Microbiol 128, 1959-1968.

Xu, X.-W., Wu, Y.-H., Wang, C.-S., Oren, A., Zhou, P. J. \& Wu, M. (2007a). Haloferax larsenii sp. nov., an extremely halophilic archaeon from a solar saltern of Zhe-Jiang, China. Int J Syst Evol Microbiol 57, $717-720$.

Xu, X.-W., Wu, Y.-H., Zhou, Z., Wang, C.-S., Zhou, Y.-G., Zhang, H.-B., Wang, Y. \& Wu, M. (2007b). Halomonas saccharevitans sp. nov., Halomonas arcis sp. nov. and Halomonas subterranea sp. nov., halophilic bacteria isolated from hypersaline environments of China. Int J Syst Evol Microbiol 57, 1619-1624.

Yoon, J. H., Shin, D. Y., Kim, I. G., Kang, K. H. \& Park, Y. H. (2003). Marinobacter litoralis sp. nov., a moderately halophilic bacterium isolated from sea water from the East Sea in Korea. Int J Syst Evol Microbiol 53, 563-568.

Yoon, J. H., Yeo, S. H., Kim, I. G. \& Oh, T. K. (2004). Marinobacter flavimaris sp. nov. and Marinobacter daepoensis sp. nov., slightly halophilic organisms isolated from sea water of the Yellow Sea in Korea. Int J Syst Evol Microbiol 54, 1799-1803. 